\title{
KOMMUNIKÁCIÓS CSATORNÁK ÉS AZ INNOVÁCIÓS MAGATARTÁS HATÁSA A BIZALOMRA, VALAMINT A VEVŐKAPCSOLATI TELESÍTMÉNYRE A SZEMÉLYES ÉRTÉKESÍTÉSBEN
}

\section{THE EFFECT OF COMMUNICATION CHANNELS AND INNOVATION BEHAVIOUR ON TRUST AND CUSTOMER RETENTION IN PERSONAL SELLING}

A cikk azt vizsgálja, hogy az értékesítők által használt offline és online kommunikációs csatornák, valamint az innovációs magatartása milyen hatással van a bizalomra, valamint a vevőmegtartásra. Az elemzéshez PLS-SEM modellt használtak a szerzők, amely megfelelő feltáró modellalkotásnál, valamint robusztus kisebb elemszámnál is.

Eredményeik rámutatnak arra, hogy az offline és az online kommunikáció egyaránt pozitív hatással van a bizalomra, vagyis a minőségi kapcsolattartás - függetlenül annak módjától - a bizalomépítés alapját jelenti. Emellett az innovációs magatartás is pozitív hatást gyakorol a bizalomra, valamint a vevőmegtartásra, ami kiemeli az értékesítő innovációs magatartásának jelentőségét.

Kulcsszavak: személyes értékesítés, kommunikációs csatornák, vevőmegtartás, bizalom, innovációs magatartás

The paper analyses how offline and online communication channels used by salespeople and innovation behaviour affects trust and customer retention. For the analysis PLS-SEM model was applied, which is appropriate for exploratory model construction, and robust even if the sample size is not so high.

Results highlight that both offline and online communication affect trust positively, so quality relationship-building regardless the type of relationship-building - can form the basis of trust. Besides, innovation behaviour affects trust and customer retention positively, which highlights the importance of innovation behaviour.

Keywords: personal selling, communication channels, customer retention, trust, innovation behaviour

Finanszírozás/Funding:

A publikáció a Budapesti Corvinus Egyetem által az EFOP- 3.6.1-16-2016-00013 "Intelligens szakosodást szolgáló intézményi fejlesztések a Budapesti Corvinus Egyetem székesfehérvári Campusán" című európai uniós projekt keretében készült.

\section{Szerzők/Authors:}

Dr. Bauer András, egyetemi tanár, Budapesti Corvinus Egyetem (andras.bauer@uni-corvinus.hu)

Dr. Mitev Ariel, egyetemi docens, Budapesti Corvinus Egyetem (ariel.mitev@uni-corvinus.hu)

Dr. Gáti Mirkó, egyetemi adjunktus, Budapesti Corvinus Egyetem (mirko.gati@uni-corvinus.hu) 


\section{Az észlelt bizalom és a kommunikáció szerepe a vevőmegtartásban: Egy összekötői perspektíva}

Mind a hálózatok kialakulásában, mind pedig azok fenntartásában jelentős - bár változó - szerepe van a szervezeteket összekötő munkatársaknak. Az e pozíciókban dolgozók (vö. Keszey, 2018: boundary spanner) a szervezetek határán töltik be egy vagy több szervezetet összekapcsoló tevékenységüket. Keszey (2014) megközelítésében e feladat elvégzésében például a marketingszakembereknek és az értékesítőknek is fontos szerepük van. Munkájuk érdekes, de nem mentes a konfliktusoktól, amelyek a helyzetböl fakadnak, egyszerre kell saját vállalatuk és a vevő érdekeit képviselniük, ami óhatatlan súrlódásokhoz, gyakran konfliktusokhoz vezet. Az összekötői szerepek több személyhez és szereplőhöz köthetők, s tradicionálisan az értékesítők/beszerzők töltik be azokat. Ez a szerepkör számos ok miatt változik, amelyeket az üzleti folyamatok és a technológiai változások egyaránt indukálnak. Az egyik ilyen folyamat az ún. trade marketing megjelenése volt (Dupuis \& Tissier-Desbordes, 1996), ahol a nagy ügyfelek már nem egy személyen (klasszikusan egy kiemelt ügyfélmenedzser) kapcsolódnak egymáshoz, hanem mindkét oldalon egy-egy interfunkcionális projektcsapat müködik, jóllehet gyakran az értékesítők által vezetve. Hasonló folyamatok zajlanak le a beszerzés területén is, amelynek stratégiai jelentősége folyamatosan növekszik (v.ö. pl. Gadde \& Håkansson, 1994), illetve az online technológia használata révén a beszerzők jóval több forrásból képesek a szállítóról információt szerezni. (v.ö. LinkedIn, 2017). E tényezőkre reagálva az értékesíteni szándékozó vállalatok jelentős befektetéseket végeztek a digitalizáció területén, hogy vevőik elégedettségét növeljék. Felmerül a kérdés, hogy az értékesítők egyik legfontosabb „fegyvere”, a bizalom szerepe fennmarad-e az új körülmények között, vagy ha változik, milyen formában?

\section{A szervezetközi kapcsolatok és a bizalom}

Kutatásunkban a szervezetközi kapcsolatok egy speciális megjelenési formáját, az értékesítők által észlelt helyzetet elemezzük. A szervezetek között több szinten és formában jönnek létre formális és informális kapcsolatok, amelyek a hálózatok építőelemei. Wehmeyer és társai (2001) szerint ezek különböző szinteken jelennek meg, személyes, vállalati és absztrakt hálózati szinten. $\mathrm{E}$ kapcsolatok egyaránt magyarázhatók attitűdök és specifikus magatartásformák (bizalom, elkötelezettség, információmegosztás stb.) oldaláról. A személyes kapcsolatokat gyakran alakítják az érzelmek, a szervezetközi kapcsolatokat pedig inkább a racionalitás formálja. A szervezetközi kapcsolatok egyik lényeges eleme a bizalom, és a bizalom hatással van a kapcsolatok kimenetére is (Ashnai et al., 2016). McEvily et al. (2003) megközelítésében a bizalom szervezetközi kapcsolatokban komplex módon járulhat hozzá a szervezeti tényezők szervezéséhez és mobilizálásához, ezáltal például az üzleti csere számára, egy eladóvevő szituációban elengedhetetlen tényezőként szerepel.

A bizalom több társadalomtudományi elmélet középpontjában áll, amikor a társas, illetve üzleti kapcsolatokat elemzik. Míg a neoklasszikus közgazdaságtan irracioná- lisnak tartja, a tranzakciós költségek gazdaságtana bizonyos esetekben (piaci hibák esetében) költségcsökkentő tényezőként fogja fel, amely a hosszabb távú együttműködést is támogatja, és ezáltal pozitív hatással lehet a teljesítményre (Keszey, 2015). A bizalom egyaránt támaszkodik az érzelmekre, de a - különösen a szervezetközi piacon - a kalkulatív és magatartási elemek is meghatározzák azt. A marketingelméletben különösen az értékesítési utak elemzésekor gyakori változó, s jelentős szerepet kap eladó és vevő közötti kapcsolatépítésben, mint ahogy azt Dwyer et al. (1987) bemutatják.

\section{A bizalom a digitális világban}

A digitális világban átalakulnak a kapcsolatok, a személyes kommunikáció (face-to-face) hiányában, vagy annak háttérbeszorulásával párhuzamosan. Mivel a bizalom részben érzelmi alapú, vagy legalábbis mind érzelmi, mind racionális elemei léteznek, azon ingerek hiánya, melyek a nem-verbális személyes kommunikációhoz kötődnek (testtartás, mimika stb.) nehezebbé teszi, illetve átalakítja a bizalom kialakulásának folyamatát. Erle és társai (2018) - egy idegenekkel való bizalom kialakulását elemző - tanulmányukban a személyek megjelenését elemezték és arra jutottak, hogy az első vizuális benyomás befolyásolja a bizalom várható kialakulását. Természetesen tudatában vagyunk annak, hogy a bizalom kialakulása időbeni folyamat, melyet kalkulatív elemek és a másik fél megfigyelt magatartása befolyásol, amit az online kommunikáció segíthet.

A digitális bizalom fogalmát több kutatási irányzat is részletesen elemzi. Az információtechnológiai kutatások egyik fö belátása, hogy az online térben az alanyok rutindöntéseik során a rendszer által kínált forrásokat használják a bizalom növelésére, mint például a biztonságot garantáló elemeket (az oldal biztonsága, biztonságos fizetési lehetőség stb.), vagy többek között mások véleményét és értékelését. A bizalom tehát részben a rendszer szintjén már kialakul. Roghanizad és Neufeld (2015) azonban arra is felhívja a figyelmet, hogy hirtelen döntési szituációkban már megjelenik az intuíció szerepe is, azaz a döntéshozók nemcsak a rendszer által kínált „objektív” információt mérlegelik, hanem érzelmi elemek (színek, designelemek, metaforák) is megjelennek a döntésükben. Ez a megközelítés egybevág azokkal a kutatásokkal, amelyek szerint a bizalom kialakulása során az érzelmek a folyamat minden elemében megjelennek. van Zeeland-van der Holst és Henseler (2017) kutatásukban az ún. duális információértékelés (dual-processing) szerepét elemezték a bizalom kialakulásában idegtudományi módszerekkel, s megállapításuk szerint érdemes - legalábbis a személyes szinten az érzelmek szerepét a bizalom kialakulási folyamatának későbbi szakaszaiban is mérlegelni, amikor a domináns nézet szerint a magatartási hatások és a kalkulatív elemek játsszák a fö szerepet. Ez a belátás érdekes kiegészítője lehet a jelenlegi szakirodalomnak (vö. pl. Gelei \& Dobos, 2016).

Az online bizalom kialakulásában ugyan hiányoznak az előbb említett személyes elemek, de újabb perspektívák nyílnak a bizalom létrejöttére. Pagani és Pardo (2017) értelme- 
zésében a digitális technológiák alkalmazása három szinten jelenik meg; gyorsítja és hatékonnyá teszi a tevékenységeket, új erőforrásokat von be és azok kombinációját teszi lehetővé, valamint új szereplöket kapcsol össze és erösíti a közöttük lévő kapcsolatot. Mindez egybevág Quinton és Wilson (2016) megfigyelésével is, amely szerint az online hálózatok nemcsak megbízható új szereplőkkel bővülnek, hanem azokban újfajta együttmüködés is megjelenik, a közös problémamegoldás, ami nyilvánvalóan a bizalom növekedéséhez vezet. A közös problémamegoldás növeli a szereplők közötti elkötelezettséget, ami a bizalom egyik következménye és végső soron teljesítménynövelő hatású. Ez az újfajta bizalom gyorsabban jöhet létre korábban nem ismert szereplök között, de nemcsak érzelmi, hanem magatartási alapú is. Mindezt - és az információtechnológiának a bizalomhoz való hozzájárulását - jól mutatja be Levina és Vaast (2006) tanulmánya, amely a technológia hatását szemlélteti az összekötő folyamatokra.

\section{Az online és offline kommunikáció kapcsolatai és szerepe a kapcsolatok fenntartásában}

$\mathrm{Az}$ értékesítök müködési környezete folyamatosan változik, melyekhez a hálózat minden szereplőjének alkalmazkodni szükséges. Cuervas (2018) az értékesítési munka változásait elemezve számos változást azonosított, beleértve a globalizációt (új szereplők megjelenése), a változó technológiai környezetet (eltolódás az online platformokon keresztül történő beszerzés irányába), valamint a kommunikáció változásait (új kommunikációs technológiák megjelenése).

A vállalati gyakorlatban a hagyományos és az online kommunikáció párhuzamosan zajlik. Murphy és Sashi (2018) a szervezetközi piacon készült tanulmányukban azt a kérdést vizsgálták, milyen területen erősebb a személyes, illetve a digitális kommunikáció használata, és hogyan járulnak hozzá az elégedettség növeléséhez. A személyes kommunikáció erősebb hatást gyakorolt az eladó-vevő kapcsolat ápolására, jobban ösztönözte a reciprocitást és a visszajelzést, míg a digitális kommunikáció hatásosabbnak bizonyult a racionális információmegosztásban. Mindez egybeesik azzal a kutatási eredménnyel, miszerint a digitális kommunikáció fókuszáltabb és jobban használható célfeladatok területén, míg az offline kommunikáció jobban építi a személyes kapcsolatokat. Baraldi és Nadin (2006) megközelítésében pedig a különféle online IT-rendszerek tudatos beépítése az üzleti folyamatokba hosszú távon hozzájárulhat a kapcsolatok fenntartásához.

\section{Az értékesítők innovációs magatartása}

\section{Bizalom és innováció}

Az innováció meghatározása sokféleképpen történhet. Esetünkben az értékesítő szemszögéből a vevő számára nyújtott szolgáltatások révén a folyamatinnovációk azokat a módszereket jelentik, amelyek révén termékek vagy szolgáltatások új vagy jelentősen javított formában jutnak el a fogyasztókhoz (Agárdi et al., 2017, p. 809). A szervezetközi piacon a külső innováció beépülése az értékláncba egyre nagyobb jelentőségü. Mivel az innováció forrásai változóban vannak és folyamatosan bővülnek (vö. open innovation, Chesbrough, 2003), ezért valamennyi hálózati szereplő (pl. eladók és vevők) számára olyan megoldásokat szükséges találni, amelyek a leghatásosabb módon biztosítják az innováció tárgyának megtalálását és alkalmazását a vállalati folyamatokban. Az értékesítők számára ez feladataik bővülését, a hálózatban betöltött szerepük esetleges változását (pl. egy értékesítő a LinkedIn-en szakértővé válik) és a vállalati szervezetben betöltött szerepük változását jelentheti. Mindez módosíthatja az értékesítők feladatát és összekötő szerepének bővülését. Ez a bővülés egyaránt megjelenhet a vállalaton belüli szerep változásában, a vevővel való kapcsolattartásban és a hálózatban betöltött szerep változásában is. Kuester és társai (2017) tanulmányukban az értékesítők új termék fejlesztésbe történő integrációját elemezték és megállapították, hogy a fejlesztési folyamatba történő integrálás révén az értékesítők jobban voltak képesek összekötő szerepüket betölteni, ezáltal pedig a vevői bizalmat növelni.

\section{Vevőmegtartás és innováció}

A piaci szereplők által közösen létrehozott innováció a kapcsolatrendszer szintjén alapvetően az egyéni problémamegoldó folyamat során létrejövő hozzáadott értéknek köszönhetően jött létre (Ryan \& O’Malley, 2016). Ebből a szempontból az értékesítő egyéni összekapcsoló szerepe (boundary spanner) és a társadalmi tőke importja együtt képes kiaknázni az eladó-vevő kapcsolatban rejlő üzleti potenciált. Az összekapcsoló szerepben müködő értékesítő így adott esetben képes a hálózatépítésre. Az innováció lehetséges előnyei a szervezet számára a partnerkapcsolatok szempontjából olyan terület, amelyik sok érdekes kérdést rejt magában, hiszen végső soron annak megértése a tét, hogy az értékesítők különféle képességei mentén (pl. innovációs képesség, ld. Ryan \& O’Malley, 2016) az értékesítők milyen módon járulhatnak hozzá hosszú távon az üzleti kapcsolatban rejlő lehetőségek kiaknázásához. Az értékesítői szereppel így együtt jár az innovációk és azok eredményeinek (pl. vevőmegtartás) menedzselése, emellett pedig képesek lehetnek a két tényező közötti kapcsolat megteremtésére is (Holmes \& Smart, 2009).

\section{Hipotézisalkotás}

A bizalomnak számos elönye van, melyet mind a közgazdaságtani, mind a marketingirodalom számos tanulmánya elemzett. A közgazdasági hatások lényege, hogy a szereplők közötti bizalom a súrlódásos piacokon csökkenti a tranzakciós költségeket (v.ö. Williamson, 1989), illetve a rendszerszintü bizalom esetén olyan pozitív externáliák születnek, melyek egy hálózat valamennyi szereplője számára előnyt jelentenek. A piaci szereplők közötti bizalom nemcsak emocionális jelenség, hanem magatartási is, ahol egy vállalatpár, vagy egy hálózat tagjai a múltbeli magatartásból vonnak le következtetéseket. Anderson és Narus (1990) szerint e magatartásmintának a pontos, gyakori kommunikáció is eleme lehet, s így azt feltételezzük, hogy...

H1: Az offline kommunikáció pozitiv hatással van a bizalomra. 
Az üzleti szereplök közötti online kommunikáció jelentősége megkérdőjelezhetetlen, szinte nincs olyan vállalat, amely ne rendelkezne a digitális kommunikáció valamely eszközével, s ne használná azokat a partnerekkel való kapcsolattartásban. Mintánkban szinte minden megkérdezett legalább két digitális eszközt használt a kommunikációban. Az olyan IT-alkalmazások, mint az e-közösségek (blog, wiki stb.), az üzenetküldés (e-mail, instant messaging, mobil üzenetküldés), a konferencialehetőség (multimédia), a portálok, a groupware-k, a vállalati szintű alkalmazások lehetővé teszik a hálózatépítést. Mint korábban bemutattuk (vö. Quinton \& Wilson, 2016, vagy Pagani \& Pardo, 2018) az online kommunikáció (például közösségi platformokon keresztül) alkalmas a hálózatépítésre, hiszen annak sok eleme (reciprocitás, megosztás) megjelenik, s aminek révén a bizalom új dimenziókkal bővülhet. E hatások alapján feltételezzük, hogy...

H2: Az online kommunikáció pozitív hatással van a bizalomra.

A vevők megtartása általában alapvető üzleti cél, amelyet számos elemzés is támogat. Vázquez Gallo és társai (2014) értelmezése szerint a megfelelö ügyfelek megtartása jelentős nyereségtöbbletet jelenthet a vállalatok számára, melyet számos eszközzel lehetséges. Jahromi és társai (2014) a szervezetközi piacon elemezték a vevőmegtartás eszközeit, s úgy találták, hogy a személyre szabott és megfelelö időben tett pontos ajánlatok növelik a megtartás lehetőségét. Ezek az információk egyaránt származhatnak online és személyes forrásokból, mint pl. CRM-rendszerekből, illetve értékesítőktől...

H3: Az offline kommunikáció pozitiv hatással van a vevömegtartásra.

A vevőkapcsolatok fennmaradása számos tényezőtől függ, melyek között a kommunikáció is szerepet kap. Jaiswal és társai (2018) egy online iparágban elemezték a vevőkapcsolatokat és elemzésük szerint a kommunikáció gyakorisága és intenzitása pozitívan hat azokra. Mindezek alapján feltételezzük, hogy...

H4: Az online kommunikáció pozitív hatással van a vevőmegtartásra.

A klasszikus elméleti megközelítés szerint az értékesítőnek két feltételt kell teljesítenie ahhoz, hogy a vevője megbízzon benne: képesnek és hajlandónak kell lennie arra, hogy a megfelelő minőségben leszállítsa a kért terméket vagy szolgáltatást (Sichtmann, 2007). Ahogy az értékesítők egyre inkább képessé válnak arra, hogy felismerjék egyre növekvő szerepüket az újtermék-fejlesztésben, a szolgáltatások kialakításának újszerü megoldásaiban, valamint a vevői igények és problémák minél teljesebb körü kielégítésében, úgy növelhető szerepük a kölcsönös bizalom tekintetében (Zhang et al., 2011; Bravo, 2014). Ez alapján úgy véljük, hogy...

\section{H5: Az innovációs magatartás pozitív hatással van a} bizalomra.

Ahhoz, hogy az értékesítők fel tudják ismerni és követni tudják az általuk kiszolgálandó vevői szegmensek igényeit, szükségük van arra a tudásra, amely magában foglalja az értékesítendő termék vevői igényekre szabott tulajdonságait is, de sokszor az újtermék-információk értékesítőoldali ismereteit is (Kuester et al., 2017). Agárdi és társai (2017) szerint az innováció minden formája a teljesítmény pozitív irányú változását feltételezi. Az értékesítők egyéni összekapcsoló szerepük révén sokfajta kiegészítő jellegü, hozzáadott értéket jelentő, innovatív meglátással szolgálhatnak a vevői igényekre reagálva, ezért azt feltételezzük, hogy...

H6: Az innovációs magatartás pozitív hatással van a vevömegtartásra.

A szervezetközi piacon gyakori a hosszabb távú együttmüködés lehetősége, ahol a bizalomnak mind az érzelmi, mind a tapasztalati alapjai értelmezhetők. Gounaris (2005) kutatása szerint a magas minőségü vevőkiszolgálás alapján kialakult bizalom a feleket a kapcsolat folytatására ösztönzi. Hasonló figyelhető meg a nagy rendszerekben, ahol a tartós bizalom a rendszer szereplöit a rendszerben való maradásra ösztönzi (Piricz, 2013). Az értékesítőknek tehát érdeke a bizalom létrehozása, ezért úgy véljük, hogy...

\section{H7: A bizalom pozitív hatással van a vevömegtartásra.}

Hipotéziseink összefüggéseit szemlélteti az 1. ábra, amely egyben kutatásunk elméleti keretrendszerét is képezi.

\section{1. ábra A kommunikációs csatornák,}

valamint az innovációs magatartás hatása a bizalomra és a vevőkapcsolati teljesítményre

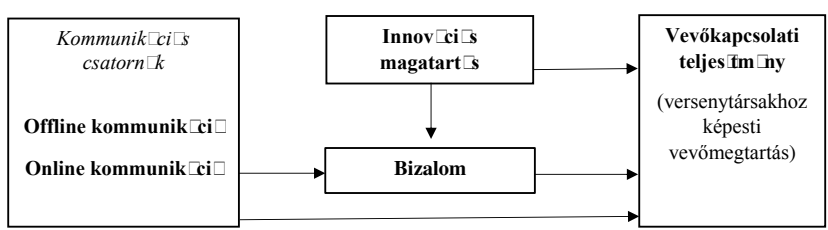

Forrás: saját szerkesztés

\section{Adatgyűjtés és mintavétel}

A mintavétel célja volt, hogy minél több iparágból találjunk olyan értékesítőket, akik egy interjú után önként hajlandóak kitölteni egy kérdöívet. Az adatfelvételre 2018 tavaszán került sor, és összesen 159 értékelhető kérdöívet kaptunk. A kitöltők főként olyan eltérő ágazatokból kerültek ki, mint FMCG, telekommunikáció, pénzügy-biztosítás, gépkocsi. A válaszadók 66\%-a férfi, 34\%-a nő, az életkor mediánja 40 év, az értékesítésben eltöltött idő mediánja 10 év.

A modell tesztelésére a varianciaalapú strukturális egyenletek modelljének egyik típusát, a PLS-SEM-et használtuk, és az elemzést az Adanco szoftverrel (Dijkstra \& Henseler, 2015) végeztük el. A PLS-SEM használatát a kutatás feltáró jellege, valamint a minta alacsony elemszáma is indokolttá tette (ld. pl. Hair et al., 2012). 


\section{A mérőeszközök és a mérési modell minőségi kritériumai}

A kutatásban elsősorban nemzetközi kutatásokban már tesztelt, vagy általunk adaptált, azaz általunk a személyes értékesítés sajátosságaira szabott skálákat használtunk (ld. 1. melléklet).

Az online, valamint az offline kommunikáció konstrukciók mérésére Jayachandran et al. (2005) négy állításból álló kommunikációs skáláját adaptáltuk az értékesítőkre, megkülönböztetve, hogy arra online vagy offline csatornán kerül sor. Az innovációs magatartás mérésére Schwepker és Schultz (2012) értéknövelő magatartást mérő skáláját adaptáltuk a személyes értékesítésre, amelynek lényege, hogy az értékesítő milyen mértékben innovatív a vevők problémáinak és igényeinek megoldásában. A bizalom konstrukció mérésére Hawes et al. (1989) módosított skáláját használtuk. A vevőkapcsolati teljesitményt Trainor et al. (2014) négy állításból álló skálája alapján mértük, amely a vevőmegtartást a versenytársakhoz viszonyítva méri. A teljesítmény értelmezését sokféle megközelítésben lehet górcső alá venni (vö. Szabó, 2012), mi azonban első sorban az értékesítők oldaláról, a vevőmegtartás szempontját figyelembe véve alakítottuk ki a teljesítményt mérő skálánkat.

Mindegyik állítást 1-7-ig tartó Likert-skálával mértük. A számos adaptált vagy módosított skála a PLS-SEM alkalmazását kívánja meg.

A konvergencia érvényességek egyrészt a standardizált faktorsúlyok segítségével ellenőrizhetők, amelyeknek meg kell haladniuk a 0,5-ös, de jobb, ha a 0,7-es értéket (Hair et al., 2012). Az 1. melléklet a konstrukciók belső konzisztencia megbízhatósági mutatóját, a Dijkstra-Henseler-féle rho $(\rho \mathrm{A})$ értékeit is mutatja, ami mindenhol bőven felette van a kívánt 0,7-es értéknek (Dijkstra \& Henseler, 2015). A konvergenciaérvényesség teljesülésére használt mutató az AVE (átlagos kivonatolt variancia), ahol a 0,5-ös értéket kell meghaladni minden egyes konstrukció esetében (Hair et al., 2012). Az AVE az 1. táblázat diagonálisában található, az adatok az elöírt kritériumoknak megfelelnek.

A diszkriminancia érvényességet Fornell és Larcker (1981) tesztje alapján mértük, mely szerint az AVE-mutatónak minden esetben nagyobbnak kell lennie, mint a konstrukciók közti korreláció négyzete. Az 1. táblázatból látható, hogy ez a kritérium teljesül.

1. táblázat A Fornell-Larcker kritérium

\begin{tabular}{|c|c|c|c|c|c|}
\hline Konstrukció & Bizalom & $\begin{array}{c}\text { Offline } \\
\text { kommunikáció }\end{array}$ & $\begin{array}{c}\text { Online } \\
\text { kommunikáció }\end{array}$ & $\begin{array}{l}\text { Innovációs } \\
\text { magatartás }\end{array}$ & Vevömegtartás \\
\hline Bizalom & 0,5822 & & & & \\
\hline Offline kommunikáció & 0,0880 & 0,7424 & & & \\
\hline Online kommunikáció & 0,1102 & 0,0186 & 0,6688 & & \\
\hline Innovációs magatartás & 0,0730 & 0,0016 & 0,0705 & 0,7716 & \\
\hline Vevömegtartás & 0,1105 & 0,0391 & 0,1263 & 0,1193 & 0,7654 \\
\hline
\end{tabular}

Megjegyzés: A diagonálisban az AVE értékei találhatók, a diagonális alatti értékek a konstrukciók közötti korrelációk négyzetei.

Forrás: saját szerkesztés, Adanco szoftver alapján

A diszkriminancia érvényességét egy manapság egyre népszerübb mutató, a HTMT segítségével is vizsgáltuk, amely szintén a faktorok közti korrelációra épít (pontosabban annak felső korlátjára), és akkor jelenthetjük ki egyértelmü- en, hogy két konstrukció különbözik egymástól, ha a HTMT szignifikánsan kisebb, mint egy (Henseler et al., 2015). Ez a kritérium esetünkben az összes konstrukciópárnál teljesül.

Összességében elegendő statisztikai bizonyítékot találtunk az öt konstrukció létezésére, valamint arra, hogy a mért változók megfelelő indikátorai a hozzájuk tartozó faktoroknak.

\section{A strukturális modell és az eredmények}

A PLS modellezésben jelenleg egyetlen modellilleszkedési mutatót használnak, az SRMR-t, amelynek küszöbértéke 0,08 (Hu \& Bentler, 1999). Az általunk felrajzolt modell illeszkedése megfelelö, mivel az SRMR=0,069. Az eredmények alapján látható (2. táblázat és 2. ábra), hogy a hipotézisek közül nem mindegyiket tudjuk elfogadni.

\section{2. táblázat Direkt hatások a modellben}

\begin{tabular}{lrrr}
\hline Direkt hatások & Együttható & t-érték & p-érték \\
\hline Offline kommunikáció -> Bizalom (H1) & 0,2553 & 3,8060 & 0,0001 \\
Online kommunikáció -> Bizalom (H2) & 0,2455 & 3,0037 & 0,0014 \\
Offline kommunikáció -> Vevőmegtartás & & & \\
(H3) & 0,1098 & 1,3679 & 0,0858 \\
Online kommunikáció -> Vevőmegtartás & & & \\
(H4) & 0,2237 & 2,0023 & 0,0228 \\
Innovációs magatartás -> Bizalom (H5) & 0,1948 & 2,3458 & 0,0096 \\
Innovációs magatartás -> Vevőmegtartás & & & \\
(H6) & 0,2380 & 2,9625 & 0,0016 \\
Bizalom -> Vevőmegtartás (H7) & 0,1613 & 1,8633 & 0,0314 \\
\hline
\end{tabular}

Forrás: saját szerkesztés, Adanco szoftver alapján

Mind az offline $(\beta=0,26)$, mind pedig az online kommunikáció $(\beta=0,25)$ pozitív hatással van a bizalomra (H1 és H2 hipotézis elfogadása), ráadásul a két különböző kommunikációs csatorna közel azonos mértékű hatást gyakorol a bizalomra. Az aktív kapcsolattartás tehát a bizalomépítés alapját jelenti, függetlenül attól, hogy személyesen vagy online módon történik. Minél minőségibb ugyanis a kapcsolattartás a vevőkkel, annál inkább erősíthető az eladó és a vevő közti bizalom.

Míg az online kommunikáció direkt hatása a vevőmegtartásra szignifikáns $(\beta=0,22)$ (H4 hipotézis elfogadása), addig az offline kommunikáció direkt hatása nem szignifikáns $(\beta=0,11)$ (H3 hipotézis elutasítása). Ha azonban a teljes hatást tekintjük (amelybe a direkt hatás mellett az indirekt hatás is beletartozik, ami ebben az esetben a bizalmon keresztül vezető út), akkor más szignifikáns összefüggést kapunk $(\beta=0,15$; t-érték $=1,893$; p-érték $=$ 0,029), bár az együttható mértéke továbbra sem túl nagy. $\mathrm{Az}$ offline kommunikáció tehát direkt módon nem hat ugyan a vevőmegtartásra, azonban a bizalmon keresztüli közvetett úttal együtt már statisztikailag szignifikáns összefüggés mutatható ki. Feltételezhetjük, hogy az értékesítök véleménye szerint a hagyományos kommunikáció elsődlegesen bizalomépítö jellegü.

A kommunikáció mellett az innovációs magatartás is hatással van a bizalomra $(\beta=0,19)$, vagyis minél inkább innovatívabb az értékesítő a vevőkiszolgálásban, annál inkább növelhető a két fél közötti bizalom mértéke (H5 hi- 
potézis elfogadása). Az innovatív magatartás annak a jele, hogy az értékesítő nemcsak odafigyel a vevők igényeire és problémáira, hanem azokat szeretné innovatív módon megoldani. Ez a magatartás azért erősíti a bizalmat, hiszen egyértelműen az együttműködésre épít, az értékesítő tartalmas (értéknövelt) segítséget nyújt a partnereinek.

Az innovációs magatartás pozitívan hat a vevőmegtartásra is $(\beta=0,24)$, ami még tovább erősíti ennek a tényezőnek a fontosságát. Vagyis minél inkább innovatívabb az értékesítő partnerei kiszolgálásánál, annál jobb lesz a vevőkapcsolati teljesítménye (H6 hipotézis elfogadása).

Végül a bizalom pozitív hatással van a vevőmegtartásra $(\beta=0,16)$, bár az együttható értéke nem túlságosan magas.

2. ábra Strukturális modell és az eredmények

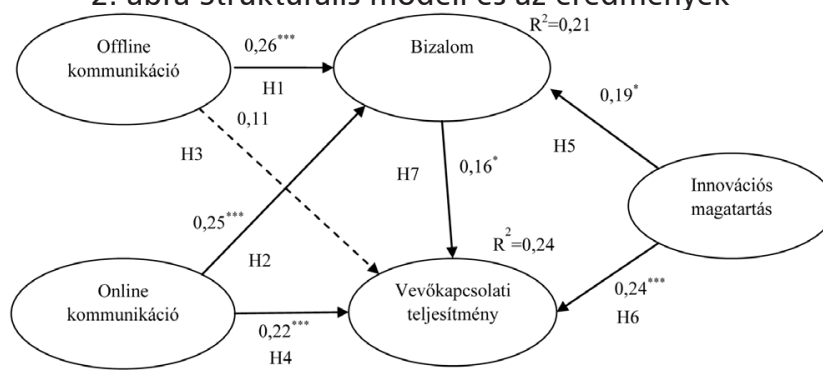

Forrás: saját szerkesztés

Megjegyzések: Az összes koefficiens standardizált ( ${ }^{* * *} \mathrm{p}$ $<0,001$; $\left.{ }^{*} p<0,05\right)$. A pontozott vonal az elvetett hipotéziseket (direkt hatásokat) ábrázolja.

\section{Következtetések és javaslatok}

Eredményeink megmutatják, hogy az offline és az online kommunikáció egyaránt pozitív hatással van a bizalomra, mind pedig a vevőmegtartásra (bár az offline kommunikációnál direkt hatás nem mutatható ki a vevőmegtartásra). Az aktív és minőségi kapcsolattartás tehát - függetlenül attól, hogy személyesen vagy online módon történik - a bizalomépítés alapját jelenti.

Emellett az innovációs magatartás pozitív hatást gyakorol a bizalomra, valamint a vevőmegtartásra is, ami kiemeli az értékesítő innovációs magatartásának jelentőségét.

Menedzsmentszempontból erősödik a dilemma az online és offline csatornák szerepe, azok átjárhatósága, valamint azok bizalomra és vevőmegtartásra gyakorolt hatása között. Kétségtelen, hogy a személyes értékesítés klasszikus, offline kommunikációja csak csekély számú partner esetében tartható fenn hosszabb távon megfelelő hatékonysággal, és nagyobb számú ügyfélnél jobban áttevődik a hangsúly az online csatornáknál. Ugyanakkor megfigyelhetö, hogy a magyar piacon az online és offline csatornák összehangoltságának problematikája még nem megoldott. Ezért is használjuk inkább a minőségi kommunikáció kifejezést a gyakori kommunikáció helyett, mivel egyrészt a gyakori interakció nem feltétlenül jelent mély kapcsolatot, másrészt a vevők típusától függ, hogy pontosan milyen kapcsolatra van igényük.
Világos az is, hogy a bizalom megteremtése, valamint a vevők megtartása érdekében nem elégséges a minőségi kommunikáció, hanem valamilyen plusz szolgáltatást is kell nyújtani, mint például az innovatív magatartást. Az innovatív magatartást azért emeltük ki, mert ahhoz, hogy hatékonyan müködjön, egyértelmüen a minőségi együttmüködésre kell épülnie, ami a bizalom létrehozásának alapja.

A kutatásnak természetesen több korlátja van. Az egyik legfontosabb korlát a minta nagysága és összetétele, valamint azt is figyelembe kell venni, hogy a konstrukciók az értékesítők észlelésein alapultak. Tehát mivel vizsgálatunkban az értékesítői benyomások elsődlegessége dominált, a jövőben érdemes három szereplő szemszögéből vizsgálódni. Az egyéni szinten szerepelhet a jövőben is az értékesítő álláspontja, a szervezeti szinten viszont szükség van egyfajta holisztikus, értékesítő szervezeti érdekeket figyelembe vevő aspektusra, harmadrészt pedig a vevői perspektívára az elemzésnél, hogy teljesebb képet kapjunk a technológia és a közösségi média jelenségéről (vö. Lacoste, 2016) az értékesítésben. Emellett izgalmas jövőbeli kutatási irányt jelenthet az innovációs magatartás kialakításának feltételéül szolgáló tényezők feltárása, valamint a már létező innovációs magatartás fejlesztési lehetőségeinek elemzése.

\section{Felhasznált irodalom:}

Agárdi I., Alt M. A., \& Berezvai Z. (2017). A nemzetközi diverzifikáció, az innováció és a teljesítmény kapcsolata az európai élelmiszer-kiskereskedelemben. Közgazdasági Szemle, 64(7-8), 805-822.

Anderson, J. \& Narus, J. (1990). A model of distributor firm and manufacturer firm working partnership. Journal of Marketing, 54(1), 42-58. doi: 10.2307/1252172

Ashnai, B., Henneberg, S. C., Naudé, P., \& Francescucci, A. (2016). Inter-personal and inter-organizational trust in business relationships: An attitude-behavior-outcome model. Industrial Marketing Management, 52, 128-139. doi: 10.1016/j.indmarman.2015.05.020

Baraldi, E. \& Nadin, G. (2006). The challenges in digitalising business relationships: The construction of an IT infrastructure for a textile-related business network. Technovation, 26(10), 1111-1126. doi: 10.1016/j.technovation.2005.09.016

Bravo, M. I. R. (2014). Opening up innovation in buyersupplier relationships: Empirical evidence of antecedents and its effect on supply chain competence (Working paper). University of Bath, Claverton Down, Bath, UK. Letöltés ideje: 2018.09.30. https://www.semanticscholar.org/paper/Opening-up-innovation-inbuyer-supplier-\%3A-Empirical/311dd4bdab67883549d 4f0fed065eee459ea8138

Chesbrough, H. (2003). The era of open innovation. MIT Sloan Review, 44(3), 35- 42.

Cuevas, J. M. (2018). The transformation of professional selling: Implications for leading the modern sales or- 
ganization. Industrial Marketing Management, 69, 198-208. doi: 10.1016/j.indmarman.2017.12.017

Dijkstra, T. K. \& Henseler, J. (2015). Consistent partial least squares path modeling. MIS Quarterly, 39(2), 297-316. doi: 10.25300/misq/2015/39.2.02

Dupuis, M. \& Tissier-Desbordes, E. (1996). Trade marketing and retailing: A European approach. Journal of Retailing and Consumer Services, 3(1), 43-51.

Dwyer, F. R., Schurr. P. H., \& Oh, S. (1987). Developing buyerseller relationships. Journal of Marketing, 51(2), 11-27.

Erle, T. M., Ruessmann, J. K., \& Topolinski, S. (2018). The effects of visuo-spatial perspective-taking on trust. Journal of Experimental Social Psychology, 79, 34-41. doi: 10.1016/j.jesp.2018.06.006

Fornell, C. \& Larcker, D. F. (1981). Evaluating structural equation models with unobservable variables and measurement error. Journal of Marketing Research, 18(1), 39-50. doi: 10.2307/3151335

Gadde, L. E. \& Håkansson, H. (1994). The changing role of purchasing: Reconsidering three strategic issues. European Journal of Purchasing \& Supply Management, 1(1), 27-35.

Gelei A. \& Dobos I. (2016). Bizalom az üzleti kapcsolatokban: A diadikus adatelemzés egy alkalmazása. Közgazdasági Szemle, 63(3), 330-349.

Gounaris, S. P. (2005). trust and commitment influences on customer retention: Insights from business-to-business services. Journal of Business Research, 58(2), 126-140. doi: 10.1016/s0148-2963(03)00122-X

Hair, J. F., Sarstedt, M., Ringle, C. M., \& Mena, J. A. (2012). An assessment of the use of partial least squares structural equation modeling in marketing research. Journal of the Academy of Marketing Science, 40(3), 414-433. doi: 10.1007/s11747-011-0261-6

Hawes, J. M., Mast, K. E., \& Swan, J. E. (1989). Trust earning perceptions of sellers and buyers. Journal of Personal Selling \& Sales Management, 9(1), 1-8.

Henseler, J., Ringle, C. M., \& Sarstedt, M. (2015). A new criterion for assessing discriminant validity in variance-based structural equation modeling. Journal of the Academy of Marketing Science, 43(1), 115-135. doi: 10.1108/imds-09-2015-0382

Holmes, S. \& Smart, P. (2009). Exploring open innovation practice in firm $\square$ nonprofit engagements: A corporate social responsibility perspective. $R \& D$ Management, 39(4), 394-409. doi: 10.1111/j.1467-9310.2009.00569.x

Hu, L. \& Bentler, P. M. (1999). Cutoff criteria for fit indexes in covariance structure analysis: Conventional criteria versus new alternatives. Structural Equation Modeling: A Multidisciplinary Journal, 6(1), 1-55. doi: 10.1080/10705519909540118

Jaiswal, A. K., Niraj, R., Park, C. H., \& Agarwal, M. K. (2018). The effect of relationship and transactional characteristics on customer retention in emerging online markets. Journal of Business Research, 92, 25-35. doi: 10.1016/j.jbusres.2018.07.007

Jahromi, A. T., Stakhovych, S., \& Ewing, M. (2014). Managing B2B customer churn, retention and profitability. Industrial Marketing Management, 43, 1258-1268. doi: 10.1016/j.indmarman.2014.06.016
Jayachandran, S., Sharma, S., Kaufman, P., \& Raman, P. (2005). The role of relational information processes and technology use in customer relationship management. Journal of Marketing, 69(4), 177-192. doi: 10.1509/jmkg.2005.69.4.177

Keszey T. (2018). Boundary spanners' knowledge sharing for innovation success in turbulent times. Journal of Knowledge Management, 22(5), 1061-1081. doi: 10.1108/jkm-01-2017-0033

Keszey T. (2015). Bizalom és vállalati teljesítmény. A bizalom szerepe az aszimmetrikus információk minőségének vállalati észlelésében és azok vezetői döntéshozatalban való felhasználásában. Vezetéstudomány/ Budapest Management Review, 46(6), 2-11.

Keszey T. (2014). Az értékesítés és a marketing kapcsolatának piaci tájékozódásban betöltött szerepe és meghatározó tényezői. Vezetéstudomány/Budapest Management Review, 45(3), 39-48.

Kuester, S., Homburg, C., \& Hildesheim, A. (2017). The catbird seat of the sales force: How Sales force integration leads to new product success. International Journal of Research in Marketing, 34, 462-479. doi: 10.1016/j.ijresmar.2016.08.008

Lacoste, S. (2016). Perspectives on social media and its use by key account managers. Industrial Marketing Management, 54, 33-43. doi: 10.1016/j.indmarman.2015.12.010

Levina, N. \& Vaast, E. (2006): turning a community into a market: a practice perspective on information technology use in boundary spanning. Journal of Management Information Systems, 22(4), 13-37. doi: 10.2753/ mis0742-1222220402

LinkedIn (2017). How digital is changing the B2B path to purchase - LinkedIn. https:/www.linkedin.com/pulse/how-digital-changed-b2b-path-purchase-michellethompson (Letöltés ideje: 2018. október 23.)

McEvily, B., Perrone, V., \& Zaheer, A. (2003). Trust as an organizing principle. Organization Science, 14(1), 91103. doi: $10.1287 /$ orsc.14.1.91.12814

Murphy, M. \& Sashi, C. M (2018). Communication, interactivity, and satisfaction in $\mathrm{B} 2 \mathrm{~B}$ relationships. Industrial Marketing Management, 68, 1-12. doi: 10.1016/j. indmarman.2017.08.020

Quinton, S. \& Wilson, D. (2016). Tensions and ties in social media networks: Towards a model of understanding business relationship development and business performance enhancement through the use of LinkedIn. Industrial Marketing Management, 54, 15-24. doi: 10.1016/j.indmarman.2015.12.001

Pagani, M. \& Pardo, C. (2017). The impact of digital technology on relationships in a business network. Industrial Marketing Management, 67, 188-192.

Piricz N. (2013). A bizalmat befolyásoló tényezők vizsgálata az üzleti kapcsolatokban. Vezetéstudomány/Budapest Management Review, 44(12), 14-29.

Roghanizad, M. \& Neufeld, D. J. (2015): Intuition, risk, and the formation of online trust. Computers in Human Behavior, 50, 489-498. doi: 10.1016/j.chb.2015.04.025 Ryan, A. \& O'Malley, L. (2016). The role of the boundary 
spanner in bringing about innovation in cross-sector partnerships. Scandinavian Journal of Management, 32(1), 1-9. doi: 10.1016/j.scaman.2015.09.002

Schwepker, C. H. \& Schultz, R. J. (2015). Influence of the ethical servant leader and ethical climate on customer value enhancing sales performance. Journal of Personal Selling \& Sales Management, 35(2), 93-107. doi: 10.1080/08853134.2015.1010537

Sichtmann, C. (2007). An analysis of antecedents and consequences of trust in a corporate brand. European Journal of Marketing, 41(9/10), 999-1015.

Szabó Zs. R. (2012). Bizonytalanság, stratégia és teljesítmény: Kvalitatív kutatás innovatív kis- és középvállalatok vezetői körében. Vezetéstudomány/Budapest Management, Review, 43(12), 23-30.

Trainor, K. J., Andzulis, J., Rapp, A., \& Agnihotri, R. (2014). Social media technology usage and customer relationship performance: A capabilities-based examination of social CRM. Journal of Business Research, 67(6), 1201-1208. doi: 10.1016/j.jbusres.2013.05.002

van Zeeland-van der Holst, E. M. \& Henseler, J. (2018). Thinking outside the box: A neuroscientific perspec- tive on trust in B2B relationships. IMP Journal, 12(1), 75-110. doi: 10.1108/imp-03-2017-0011

Vázquez Gallo, M. J., Estévez, M., \& Egido, S. (2014). Active learning and dynamic pricing policies. American Journal of Operations Research, 4, 90-100.

Wehmeyer, K., Riemer, K., \& Schneider, B. (2001): Roles and trust in interorganizational systems. In Proceedings of the Eighth Research Symposium on Emerging Electronic Markets (pp. 1-14). Maastricht, The Netherlands.

Williamson, O. E. (1989). Transaction Cost Economics. In Handbook of industrial organization (pp. 135-182). Amsterdam, The Netherlands: Elsevier.

Zhang, C., Viswanathan, S., \& Henke Jr., J. W. (2011). The boundary spanning capabilities of purchasing agents in buyer-supplier trust development. Journal of Operations Management, 29, 318-328. doi: 10.1016/j. jom.2010.07.001

1. melléklet A modell konstrukcióinak mérése és megbízhatósága

\begin{tabular}{|c|c|c|c|c|}
\hline Konstrukció (rho) & Állítás & Faktorsúlyok & Átlag & Szórás \\
\hline \multirow{4}{*}{$\begin{array}{l}\text { Offline kommunikáció } \\
(\rho \mathrm{A}=0,90)\end{array}$} & Lehetővé teszem a vevők számára, hogy interaktívan kommunikáljanak velem. & 0,861 & 5,87 & 1,50 \\
\hline & A vevőink többféle módon léphetnek kapcsolatba velem. & 0,869 & 5,67 & 1,66 \\
\hline & Gyakori kapcsolatot tartok fenn a vevöimmel. & 0,877 & 5,43 & 1,71 \\
\hline & Köztem és a vevőim között aktívan folyik az információk megosztása és cseréje. & 0,839 & 5,59 & 1,62 \\
\hline \multirow{4}{*}{$\begin{array}{l}\text { Online kommunikáció } \\
(\rho \mathrm{A}=0,84)\end{array}$} & Lehetővé teszem a vevők számára, hogy interaktívan kommunikáljanak velem. & 0,770 & 5,83 & 1,55 \\
\hline & A vevőink többféle módon léphetnek kapcsolatba velem. & 0,819 & 6,02 & 1,34 \\
\hline & Gyakori kapcsolatot tartok fenn a vevőimmel. & 0,842 & 5,53 & 1,59 \\
\hline & Köztem és a vevőim között aktívan folyik az információk megosztása és cseréje. & 0,838 & 5,78 & 1,46 \\
\hline \multirow[t]{4}{*}{$\begin{array}{l}\text { Innovációs magatartás } \\
(\rho \mathrm{A}=0,89)\end{array}$} & $\begin{array}{l}\text { Vevőimet innovatívan látom el a kiegészítő termékeinkhez kapcsolódó szolgál- } \\
\text { tatásokkal. }\end{array}$ & 0,745 & 5,92 & 1,14 \\
\hline & Innovatívan oldom meg a vevői problémákat. & 0,942 & 5,86 & 1,14 \\
\hline & Innovatívan szolgálom ki a vevői igényeket. & 0,934 & 5,91 & 1,11 \\
\hline & Vevőim biztosan megbízhatnak bennem. & 0,688 & 6,72 & 0,59 \\
\hline \multirow{4}{*}{$\begin{array}{l}\text { Bizalom } \\
(\rho \mathrm{A}=0,76)\end{array}$} & Vevőimnek jó okuk van arra, hogy bízzanak bennem. & 0,784 & 6,72 & 0,58 \\
\hline & Vevőimnek nincs kétségük afelől, hogy megbízzanak bennem. & 0,803 & 6,42 & 0,83 \\
\hline & Vevőim úgy érzik, hogy teljes mértékben megbízhatnak bennem. & 0,772 & 6,42 & 0,84 \\
\hline & A vevőimet, akikkel kapcsolatban állok hosszú ideig meg tudjuk tartani. & 0,914 & 6,01 & 1,35 \\
\hline \multirow{3}{*}{$\begin{array}{l}\text { Vevőmegtartás } \\
(\rho \mathrm{A}=0,90)\end{array}$} & A vevőim hosszú ideig maradnak nálunk. & 0,921 & 6,01 & 1,32 \\
\hline & A vevőim hüségesek cégünkhöz. & 0,838 & 5,77 & 1,21 \\
\hline & A vevőmegtartás nagyon fontos számomra. & 0,821 & 6,55 & 0,93 \\
\hline
\end{tabular}

Forrás: saját szerkesztés

Megjegyzés: Az összes tételt 7 fokozatú Likert-skálán mértük, ahol az 1 = az egyáltalán nem jellemző, $7=$ teljes mértékben jellemző. 